\title{
Mouse embryonic stem cells: The establishment of the system to produce differentiated cell types in vitro
}

\author{
Ana Helena da Rosa Paz ${ }^{1}$, Stephanie Rief ${ }^{2}$, Diógenes Santiago Santos ${ }^{3}$, Eckhard Wolf ${ }^{4}$, \\ Katja Prelle ${ }^{4} \&$ Elizabeth Obino Cirne-Lima ${ }^{1,3}$
}

\begin{abstract}
During the last few years, embryonic stem (ES) cells have been a new tool in cell biology which is very promising for the scientific community to develop new cell therapies. ES cells are the only cell type that can differentiate into derivates of the three primary germ layers, not only in vivo but also, and most important, in vitro. This so-called pluripotency has resulted in the field of stem cell technology going into overdrive, and the establishment of many protocols for optimal maintenance, culture, genetic transfection and in vitro differentiation. The first pluripotent cells had been derived from teratocarcinomas, maligne tumors, and showed some disadvantages. Therefore later embryonic stem cells, and now adult stem cells are getting special attention from the scientists.

In this study, we established for the first time in our country, the prolonged culture of undifferentiated ES cells in vitro and the pointed induction of cell differentiation into specific cell types. It is the result of an international collaboration program supported by Brazil and Germany, CAPES and DAAD (PROBRAL). The well-established routine should be clearly demonstrated by the continuous culture and propagation of several mouse ES lines in vitro under specific culture conditions preventing differentiation. On the other hand, these ES cells were exposed to defined differentiation induction systems to obtain specialized cells as cardiogenic, neurogenic and myogenic cell types. This demonstrates the successful procedure to induce ES cell line differentiation. In this study, we established both routine systems, with and without differentiation. This results gave us competence and possibility to develop a series of different scientific approaches.
\end{abstract}

Key words: embryonic stem cell, cardiac cell, neuronal cell, myogenic cell, R1 and D3 cell lines.

Postgraduate Program of Veterinary Sciences (Programa de Pós-Graduação em Ciências Veterinárias, Faculdade de Veterinária - FAVET), Universidade Federal do Rio Grande do Sul (UFRGS). ${ }^{2}$ Department of Physiology, Technical University Munich-Weihenstephan, Germany. ${ }^{3}$ Group of Molecular and Functional Microbiology, Department of Molecular Biology and Biotechnology, Biotechnology Center - UFRGS, RS, Brazil. ${ }^{4}$ Department of Molecular Animal Breeding and Biotechnology, Ludwig Maximilian University Munich, Germany. CORRESPONDENCE: E. O. Cirne-Lima [e-mail: bcirne@dna.cbiot.ufrgs.br; Fax +55 513316 7305] Setor de Imunologia/DPCV/FAVET UFRGS. Caixa Postal 15094; 91501-970 Porto Alegre, RS - Brazil. 
There are three types of stem cells: totipotent cells derived from the embryo, which can generate an entire organism and differentiate into all types of tissue.

Secondly pluripotent cells which can differentiate into cells of all three germ layers, but not develop to another complete individual. In the beginning pluripotent cells were isolated from teratocarcinomas, a complex type of malignant tumor containing a mixture of differentiated cell types, including derivatives of the three germ layers, and a number of undifferentiated cells, which are called embryonic carcinoma (EC) cells due to their similarity of early embryonic cells [13]. EC cells are a very good model of multilineage differentiation, but their use as a developmental model is undetermined because of their aneuploid karyotype.

Embryonic stem (ES) cells are pluripotent cell lines with the capacity of self renewal and a broad differentiation plasticity [16]. Since the first ES cell lines (sharing many features with the EC) were established from the inner cell mass (ICM) of mouse blastocysts [8] others have been derived from eighth cell embryos or dissociated from morula. ES cells are a good model for development studies, especially because ES cells do not only differentiate in vitro and in vivo, but also can be propagated as a homogeneous uncommitted cell population for an almost unlimited period of time without losing their pluripotency and their stable karyotype.

In vitro, ES cells spontaneously differentiate into many cell types, and are used to study differentiation of cardiac [11, 12, 26, 28], myogenic [17-19], haematopoietic $[21,25]$, epithelial [1], neuronal $[2,9,15]$, vascular smooth muscle [6] and adipogenic cells [3].

Considering that this cells can be propagated with the same characteristics it can be transfected with specific gene sequences and the transgenic lines obtained should be used as a model to study the influence of the expression of that specific genes on in vitro and in vivo tissue differentiation and furthermore this transgenic ES cell lines could be injected in an embryo to analyze the influence of the expression of that specific sequence upon embryo and/or animal development.

In addition, the nucleus of an embryonic stem cell transfected with a target gene or not could be injected by micromanipulation into an enucleated zygote to produce an animal clone.
The third group are the multipotent somatic stem cells, which are derived from adult, differentiated tissues and do not present the same plasticity, capacity of long-term propagation and less ability to generate different cell types. For example haematopoietic stem cells (HSCs) isolated from the bone marrow represent only a very small amount of around 1 in 15000 cells [24]. Beside the bone marrow cells, other adult tissues such as blood, brain, spinal cord, skeletal muscle, and epithelia of the skin and digestive system contain a similar type of multipotent somatic or adult stem cell population like the HSCs culture. But the main difference between embryo-derived pluripotent cells and soma-originated multipotent cells is that the latter are no longer able of generating germ cells and may also not differentiate into the wide range of cell types that can be derived from embryonic stem cells [5].

At the present report we decided to work with murine ES cell lines to induce in vitro differentiation into cardiogenic, myogenic and neurogenic cells using specific protocols established during the last years.

\section{MATERIALS AND METHODS}

\section{Cell lines}

The mouse embryonic stem cell lines D3 [4] and R1 [14] were cultured in an undifferentiated state on feeder layer cells of primary mitomycin-treated embryonic mouse fibroblasts in DMEM (Dubco's modified Eagles medium, GibcoBRL Life Technologies, GmbH) supplemented with $15 \%$ FCS, $1 \%$ non essential amino acids, $0.1 \% \beta$-mercapto ethanol, $1 \% \mathrm{~L}$-glutamine and $1 \%$ LIF as described by Wobus et al. 1984

In vitro differentiation. To initiate in vitro differentiated ES cells were passaged onto gelatin-coated plastic petri dishes $24 \mathrm{~h}$ before further treatment and cultured without LIF for $12 \mathrm{~h}$. Then ES cell colonies were disaggregated using trypsin solution $(0.2 \%$ Gibco BRL in PBS, phosphate-buffered saline) and counted using a Neubauer's chamber. Depending on the supposed direction of differentiation between 400 and 600 ES cells $/ 20 \mu \mathrm{l}$ were cultured in hanging drops for two days. Within this period the cells aggregate and generate socalled "embryoid bodies" (EB). During this period we used DMEM culture medium supplemented with $15 \%$ of DCC-FCS (FCS treated with dextrancoated charcoal to remove endogenous retinoids and hormones). Afterwards EBs were cultured in suspension 
using bacteriological petri dishes for additional 3 days. Subsequently EBs were plated individually in 24-well plates, in DMEM supplemented with $15 \%$ fetal calf serum (FCS; selected batches, Gibco), $1 \%$ L-glutamine (Gibco, $2 \mathrm{nM}$ ), 0.1\% $\beta$-mercaptoethanol (Serva, Heildelberg; final concentration $5 \times 10^{-5} \mathrm{M}$ ) and $1 \%$ nonessential amino acids (NAA; Gibco) as described [26,11].

\section{Cell culture - For differentiation system}

Cardiogenic differentiation: R1 ES cells; culture medium D-MEM (Dubco's modified Eagles medium, GibcoBRLLife Technologies, $\mathrm{GmbH}$ ) with the supplements described above plus 1\% DMSO (Gibco), 400 ES cells/20 $\mu$ microdrops, suspension culture for 7 days.

Neurogenic differentiation: D3 ES cells, Iscove's medium supplemented as described above to the DMEM plus retinoic acid (RA) $10^{-7} \mathrm{M}$, daily supplemented during the first 3 days of 7 days suspension culture. Cell density: 800 cells/drop.

Myogenic differentiation: D3 ES cells, D-MEM supplemented as described above. Suspension culture for 5 days in total, while cell density in hanging drops was 800 cells $/ 20 \mu$ l.

\section{RESULTS}

The ES cell lines cultured under specific, well defined differentiation-inducing conditions developed from an undifferentiated stage resembling pluripotent cells of the early embryo into terminally differentiated stages of cardiomyocytes, myocytes, and neuronal cells. These cells were analyzed by cell morphology and also physiological properties, $e$. g. the in vitro differentiated cardiomyocytes resembled characteristics of atrial, ventricle, spontaneously beating.
It was found that parameters like number of cells in hanging drops, media and supplementations, ES cell lines and the time of EB plating influenced the developmental potency and differentiation features of ES cells in culture.

\section{DISCUSSION AND CONCLUSIONS}

For example, RA induces differentiation of ES into specific cell types, in a time and concentration dependent manner $[3,7,9,10,20,22,23,27]$.

In this study we have successfully established for the first time in Brazil the embryonic stem cell technology including prolonged culture of various pluripotent ES cell lines as well as the directed induction of in vitro differentiation into a variety of specialized cell types like myogenic, cardiac and neuronal cells.

The present results gave us conditions to develop the ES cells routine in our University in order to apply this new technology to other projects where we will have conditions to analyze the influence of specific genes expression in tissue and animal development as well as we can collaborate with the groups of our University that dominate the animal reproduction technology to produce transgenic animals that should function as bioreactors to produce specific proteins.

Although the recent success in establishing human ES cells raised numerous public discussions concerning ethical, legal and political issues of this technique based on the idea to manipulate human embryos in order to introduce therapeutical cloning of human embryos used as sources of undifferentiated cells which subsequently will be used to generate autologous specific cell types in vitro for cell transplantation without any risk of rejection or any other side effect. Currently at the moment this topic is discussed very intensively and controversially around the world and it is necessary to define limits based on public and scientific local agreements.

\section{REFERENCES}

1 Bagutti C., Wobus A.M., Fässler R. \& Watt F.M., 1996. Differentiation of embryonal stem cellsInto keratinocytes: Comparison of wild type and $\beta$ integrin-defficient cells. Developmental Biology. 179: 184-196.

2 Bain G., Kitchens D., Yao M., Huettner J. E. \& Gottlieb D.I., 1995. Embryonic stem cells express neuronal properties in vitro. Developmental Biology. 168: 342-357.

3 Dani C., Smith A.G., Dessolin S., Leroy P., Staccini L., Villageois P., Darimont C. \& Ailhaud G., 1997. Differentiation of embryonic stem cells into adipocytes in vitro. Journal of Cell Science. 110: 1279- 1285.

4 Doetschmann T.C., Eistetter H. R., Katz M., Shimidt W. \& Kemler R., 1985. The in vitro Development of blastocystderived embryonic stem cell lines: formation of visceral yolk Sac, Blood Island and myocardium. Journal of Embryology and Experimental Morphology. 87: 27-45. 
Paz A.H.R., Rief S., Santos D.S., Wolf E., Prelle K., Cirne-Lima E.O. 2003. Mouse embryonic cells: the estabilishment of the system to produce differentiated cell type in vitro. Acta Scientiae Veterinariae. 31: 51-54.

5 Donovan P. J. \& Gearhart J., 2001. The end of the beginning for pluripotent stem cells. Nature. 414: 92-97.

6 Drab M., Haller H., Bychkov R., Erdmann B., Lindschao C., Haase H., Morano I., Luft F.C. \& Wobus A.M., 1997. From totipotent embryonic stem cells to spontaneously contracting smooth muscle cells: A retinoic acid and dbcAMP in vitro differentiation model. FASEB Journal. 11:905-915.

7 Edwards M.K. \& McBurney M.W., 1983. The concentration of retinoic acid determines the differentiated cell types formed by teratocarcinoma cell line. Developmental Biology. 98:187-191.

8 Evans M.J. \& M.H. Kaufman, 1981. Establishment in culture of pluripotential cells from mouse embryos. Nature. 292 : $154-156$.

9 Fraichart A., Chassande O., Bilbaut G., Dehay C., Savatier P. \& Samurut J., 1995. In vitro differentiation of embryonic stem cells into glial cells and functional neurons. Journal of Cell Science. 108: 3181-3188.

10 Jones-Villeneuve E.M., Rudnicki M.A., Harris J.F. \& McBurney M.W., 1983. Retinoic acid Induced neural differentiation of embryonal carcinoma cells. Molecular Cell Biology. 3: 2271-2279.

11 Maltsev V., Rohwedel J. \& Wobus A.M., 1993. Embryonic stem cells differentiate in vitro into cardiomyocytes representing sinusnodal atrial and ventricular types. Mechanical Developmental. 44: 41-50

12 Maltsev V., Wobus A.M., Rohwedel J., Bader M. \& Hescheler J., 1994. Cardiomyocytes differentiated in vitro from embryonic stem cells developmentally express cardiac specific genes and ionic currents. Circulation Research. 75: 233-244.

13 Martin G.R. \& Evans M.J., 1975. Differentiation of clonal lines of teratocarcinoma Cells: formation of embryoid bodies in vitro. Proceedings of National Academy of Science USA. 72: 1441-1445.

14 Nagy A. \& Rossant J., 1996. Production of completely ES cell-derived fetuses. In: Joyner A. (Ed). Gene Targeting: A pratical Approach. Oxford: IRL Press, pp. 147-179.

15 Okabe S., Forsberg-Nilsson K., Spiro A.C., Segal M. \& McKay R.D., 1996. Development of neuronal precuror cells and functional postmitotic neurons from embryonic stem cells in vitro. Mechanical Development. 59: 89-102.

16 Prelle K., Zink N. \& Wolf E., 2001. Pluripotent Stem Cells- Model of Embryonic Development, Tool for Gene Targeting, and Basis of Cell Therapy. Anatomy, Histology and Embryology. 31:169-186.

17 Rohwedel J., Maltsev V., Bober E., Arnold H.H. \& Wobus A.M., 1994. Muscle cell differentiation of embryonic stem cells reflects myogenesis in vivo: regulation expression of myogenic determination genes and functional expression of ionic currents. Developmental Biology. 164: 87-101.

18 Rohwedel J., Horák V., Hebrok M., Füchtbauer E.M. \& Wobus A.M., 1995. M-twist expression inhibits mouse embryonic stem cell-derived myogenic differentiation in vitro. Experimental Cell Research. 220: 92-100

19 Rohwedel J., Kleppisch T., Pich U., Guan K., Jin S., Zuscharatter W., Hopf C., Hoch W., Hescheler J., Witzemann V. \& Wobus A.M., 1998b. Formation of postsynaptic-like membranes during differentiation of embryonic stem cells in vitro. Experimental Cell Research. 239: 214-225.

20 Rudnicki M.A. \& McBurney M.V. 1987. Cell culture methods and induction of differentiation of embryonal carcinoma cell lines. In: Robertson E.J. (Ed). Teratocarcinomas and Embryonic. Stem Cells. Oxford: IRL Press, pp 19-49.

21 Shimitt R.M., Bruyns E. \& Snodgrass H.R., 1991. Hematopoietic development of embryonic stem Cells in vitro: Cytokine and receptor gene expression. Genes Development. 5: 728-740.

22 Strickland S. \& Mahdavi, 1978. The induction of differentiation in teratocarcinoma stem cells by retinoic acid. Cell. 15:393-403.

23 Strümbing C., Ahnert Hilger G., Shan J., Wiedenmann B., Hescheler J. \& Wobus A.M., 1995. Differentiation of pluripotent embryonic stem cells into the neuronal lineage in vitro gives rise to mature inhibitory and excitatory neurons. Mechanical Developmental. 53: 275-287.

24 Weissman I. L. 2000. Stem cells: units of development, units of regeneration, and units in evolution. Cell. 100: 157-168.

25 Wiles M.V. 1993. Embryonic stem cell differentiation in vitro. Methods in Enzymology. 225: 900-918.

26 Wobus A. M., Wallukat G., Hescheler J., 1991. Pluripotent mouse embryonic stem cells are able to differentiate into cardioyocytes expressing chronotropic responses to adrenergic and cholinergic agents and $\mathrm{Ca}^{2+}$ channel blockers. Differentiation. 48: 173-182.

27 Wobus A. M., Rohwedel J., Maltsev V. \& Hescheler J., 1994. In vitro differentiation of Embryonic stem cells into cardiomyocytes or skeletal muscle cells is specifically modulated by retinoic acid. Roux's Archive for Developmental Biology. 204: 36-45.

28 Wobus A. M. \& Guan K., 1998. Embryonic stem cell-derived cardiac differentiation: Modulation of differentiation and "loss-of-function" analysis in vitro. Trends in Cardiovascular Medicine. 8: 64-74. 